


\title{
Türkçe öğretmeni adaylarının dijital rozetlere yönelik algıları üzerine bir araştırma
}

\author{
Ahmet BASAL ${ }^{1}$ \\ Talat AYTAN2
}

Naime ELCAN KAYNAK3

\begin{abstract}
APA: Basal, A.; Aytan, T.; Elcan Kaynak, N. (2019). Türkçe öğretmeni adaylarının dijital rozetlere yönelik algıları üzerine bir araştırma. RumeliDE Dil ve Edebiyat Araştırmaları Dergisi, (14), 1-14. DOI: $10.29000 /$ rumelide.540989
\end{abstract}

\section{Öz}

Teknolojinin gelişmesine koşut olarak eğitim ortamlarında çeşitli teknolojik araçların kullanılması yaygınlaşmıştır. Son zamanlarda öğrenci motivasyonuna olası katkıları ve alternatif değerlendirme yaklaşımı olarak kullanılma potansiyeliyle dijital rozetlerle ilgili yapılan çalışmaların sayısı giderek artmaya başlamıştır. Söz konusu bu çalışmaların büyük çoğunluğu deneysel çalışmalardan ziyade kuramsal çerçeveyi ortaya koyan betimleyici ve önerici mahiyetteki çalışmalardır. Mevcut araştırma bu alandaki eksikliği gidermeye katkı sağlamak amacıyla gerçekleştirilmiştir. Çalışma kapsamında İstanbul'daki bir devlet üniversitesinin Türkçe öğretmenliği lisans programında öğrenim gören 48 öğrenciye bir öğretim yönetim sistemi olan Edmodo üzerinden sınıf içi performanslarına yönelik olarak dijital rozetler gönderilmiştir. On dört haftalık uygulama neticesinde katılımcıların dijital rozetler hakkındaki algılarını belirlemeye yönelik 13 maddeden ve 4 açık uçlu sorudan oluşan bir anket uygulanmıştır. Nicel veriler baz alındığında, katılımcıların dijital rozetlere karşı olumlu algılara sahip olduğu bulunmuştur. Nitel verilere yönelik içerik analizi ile dijital rozetlerin avantaj ve dezavantajlarına yönelik temalar ortaya çıkarılmıştır. Araştırma, dijital rozetlerin işe koşulması, kullanımına yönelik öğretmen algılarını belirlemesi ve uygulamaya dair öneriler sunması bakımından önem arz etmektedir.

Anahtar kelimeler: Algı, dijital rozet, Türkçe öğretmen adayları.

\section{A study on the perceptions of Turkish teacher candidates about digital badges}

\begin{abstract}
In parallel with the developments in technology, the use of various technological tools in educational environments has become widespread. Recently, the number of studies on digital badges is on the increase due to their possible contributions to student motivation and their potential of use as an alternative assessment. The majority of these studies are descriptive and suggestive studies that layout the theoretical framework rather than experimental studies. The current research has been carried out to contribute to the lack in this area. Within the scope of the study, 48 students who were
\end{abstract}

1 Doç. Dr., Yıldız Teknik Üniversitesi, Eğitim Fakültesi, Yabancı Diller Eğitimi Bölümü, (İstanbul, Türkiye), ahmetbasal@gmail.com, ORCID ID: oooo-0003-4295-4577 [Makale kaylt tarihi: 25.01.2019-kabul tarihi: 06.03.2019; DOI: $10.29000 /$ rumelide.540989]

2 Doç. Dr., Yıldız Teknik Üniversitesi, Eğitim Fakültesi, Türkçe Eğitimi Bölümü, (İstanbul, Türkiye), talataytan@gmail.com, ORCID ID: 0000-0001-9778-8970

3 Dr. Arş. Gör., Erciyes Üniversitesi, Eğitim Fakültesi, Eğitim Bilimleri Bölümü, (Kayseri, Türkiye), naimeelcan@gmail.com, ORCID ID: oooo-ooo2-2132-1124 


\begin{abstract}
studying at the Turkish Language Teaching program in a state university were sent digital badges for their in-class performances viaEdmodo, a learning management system. After fourteen weeks of application, a 13-item questionnaire and accompanying 4 open-ended questions was applied to determine the perceptions of the participants about digital badges. Based on the analysis of the quantitative that it was found that participants have positive perceptions towards the use of digital badges. Based on the content analysis to the qualitative data, themes were emerged on the advantages and disadvantages of digital badges. The current research is important since it experiments on the use of digital badges, determines the perceptions of the teachers about the use of digital badges and provides suggestions about the application.
\end{abstract}

Key words: Digital badges, perceptions, Turkish teacher candidates.

\title{
Giriş
}

İnternet, iletişim çağının en önemli teknolojik gelişmesi olmakla beraber bilgiye erişmede, bilgi alışverişinde, ölçülebilir ve değerlendirilebilir eğitim uygulamaları sunmada etkili ve verimli bir ortam olma özelliğini sürdürmektedir (Gates, 200o). Eğitim politikaları geliştirmede, öğretim programı hazırlamada, ders araç gereci tasarlamada internet teknolojisinin sunduğu imkânlar manzumesi, göz ardı edilemez bir seviyeye ulaşmıştır. Ağ topluluklarının, etkileşimli ortamların, çevrimiçi öğreticilerin, e-öğrenme ve m-öğrenme uygulamalarının faydalarının gün geçtikçe artması özel ve kamu eğitim amaçlı örgütlerin sundukları çevrimiçi öğrenme ortamlarının çeşitlenmesine zemin hazırlamaktadır (Kandemir, 2014). Öğrenenlerin zaman ve mekândan bağımsız olarak bilgi iletişim teknolojileri aracılı̆̆ıyla gerçekleştirdikleri çevrimiçi öğrenme, teknolojinin gelişimiyle birlikte farklı olanaklara sahip olmaktadır. Bu da öğrenmeye her geçen gün daha esnek bir yapı kazandırarak öğrenenin istediği anda ve yerde öğrenmesini sağlayabilmektedir (Güler \& Güler, 2015).

Son zamanlarda performans değerlendirme, motivasyon artırma, öğrenci ilgisini çekme bağlamında oyunlaştırma ögelerini de içeren dijital rozetlerin kullanılması giderek yaygınlaşmaya başlamıştır. Oyunlaştırma, özellikle ilk ve ortaöğretim çağındaki çocukların okul türü öğrenmelerinde işe koşulan bir etkinlik olarak dikkat çekmektedir. Teknolojik gelişmelere paralel olarak hedef kitlenin ilgisi geleneksel oyunlardan dijital oyunlara evrilen bir eğilim göstermektedir. Bu bağlamda elektronik ortamda oyunlaştırıcı etkinliklere yer verilmesi gündeme gelmektedir. Oyunlaştırma tasarımı içerisindeki yaygın kullanımlardan birisi de dijital rozettir (Tunga \&İnceoğlu, 2016; Werbach \& Hunter, 2012).

Dijital rozet, farklı öğrenme ortamlarında kazanılan becerilerin web sayfası, öğrenme yönetim sistemleri, sosyal uygulamalar vb. çevrim içi ortamlarda görsel olarak temsil edildiği, başarı, nitelik ve öğrenme sürecine katılımın somut kanıtı olan dijital simgelerdir (Casilli\& Knight, 2012). Genellikle oyun içerisinde gösterilen başarılarla elde edilen veya başarılan durumu temsil eden görsel ögelerdir (Bozkurt \& Genç- Kumtepe, 2014: 150). Oyun kurgusu içerisinde tanımlanan görevler tamamlandığında öğrencilerde olumlu duygular meydana getirir; dijital oyunlar da bu duyguları rozet ya da puan gibi çeşitli ödüllerle pekiştirir (Şahin \& Samur, 2017). Daha açık bir ifadeyle dijital rozetler "başarıların görsel olarak yansımasıdır" (Sailervd., 2013; 30).

Dijital rozetlere yönelik teorik ve uygulamalı alan yazından yola çıkarak Ahn, Pellicone ve Butler (2014) 3 genel tema ortaya koymuşlardır: 1)öğrenenlerin herhangi bir görevi ve/veya ödevi yapmasını teşvik edici rolünden dolayı davranış motive edici olarak rozetler 2) öğrenenlere öğrenme boyunca aktivitelerin 
amacı, öğrenme sürecinde nerede olduklarını, aktivitelerin öğrencilere ne kazandıracağını göstermesi noktasında rehberlik eden pedagojik bir araç olarak rozetler 3) öğrencinin genel başarısını gösteren diplomalara onların hangi tür bilgiye sahip olduklarını ve hangi becerilerde daha iyi olduğunu daha net gösteren işaret ve yeterlilik olarak rozetler. Araştırmacıların yaptığı bu öz inceleme, rozetlerin genel olarak nasıl ele alındığı ile ilgili belirgin bir büyük resim ortaya çıkarmaktadır.

Alan yazından hareketle dijital rozetler eğitim ortamlarında alternatif yeterlilik belirleme (Davis \& Singh, 2015), derse öğrenci katılımını artırma (Deny, 2013), derse öğrenci ilgisini artırma (Dere, Yücel \& Yalçıntaş, 2016 ; Yıldırım vd., 2014) ve özgüven artırma (Yıldırım vd., 2014) gibi katkıları yönüyle dikkate değerdir. Bunun yanı sıra motivasyon açısından dijital rozetleri ele almak gerekir. Motivasyon, bireye enerji verip onun davranış için istekli hâle gelmesinde etkili olduğundan öğrenme-öğretme sürecinin etkililiğini ön plana çıkaran en önemli faktörlerden birisi olarak karşımıza çıkmaktadır (Akbaba, 2006: Eales vd., 2002). Motivasyon, öğrencinin öğrenmesinde ve eğitim sürecinde önemli bir faktördür (Cheng, 2001). Dijital rozetlerin de öğrenenleri motive etmede işe koşulabilecek bir araç olduğunu gösteren çalışmalar da bulunmaktadır(ör: Alaswad \& Nadonly, 2015 ; Gibson vd., 2015 ; Hakulinen, 2015 ; Ylldırım vd., 2017).

Alan yazın incelendiğinde dijital rozet uygulamasına yönelik deneysel çalışmalardan ziyade kuramsal çerçeveyi ortaya koyan betimleyici ve önerici mahiyette akademik araştırmaların sayısının daha fazla olduğu görülmektedir. Mevcut araştırma dijital rozetleri işe koşarak dijital rozetlere karşı öğretmen adaylarının algılarını belirlemeye yönelik olması ile bu alandaki eksikliği gidermeye katkı sağlamak amacıyla gerçekleştirilmiştir. Çalışmanın amacı öğretmen adaylarının dijital rozet kullanımına ilişkin algılarını, perspektiflerini, ve dijital rozet kullanımının avantaj ve dezavantajlarını detaylı şekilde incelemektir. Buna yönelik olarak çalışmayı yönlendiren araştırma soruları şunlardır:

1. Öğretmen adayları dijital rozetlerin derslerinde kullanılmasını nasıl algılamaktadır?

2. Öğretmen adaylarının dijital rozetlerin eğitim sahasında kullanımıyla alakalı görüşleri, düşünceleri, bakış açıları nelerdir ve bu görüşlerin eğitime yansımaları nasıl olmaktadır?

\section{Yöntem}

Bu çalışmada İstanbul'daki bir devlet üniversitesinde öğrenim gören Türkçe öğretmeni adaylarının dijital rozetlere karşı algılarını ortaya koymak amaçlanmıştır. Bu amaç doğrultusunda 14 hafta süresince ders içindeki olası performans kriterlerine göre belirlenen dijital rozetler katılımcılara bir öğretim yönetim sistemi olan Edmodo üzerinden gönderilmiştir. Edmodo öğretmenlerin öğrencilerine bildirim yapabildigi, ders materyali paylaşabildiği, quizler oluşturabildigi bir çeşit sosyal öğrenme platformudur (Karatay vd. 2018).

Çalışmada katılımcıların dijital rozetle ilgili algılarını belirlemek için karma metod (Creswell, 2009) tercih edilmiş ve katılımcılara bu doğrultuda araştırmacılardan izin alınarak Başal ve Elcan-Kaynak'ın (2019) çalışmasındaki 13 soruluk anket ve açlk uçlu sorular gönderilmiştir. Söz konusu çalışmada İngilizce olarak uygulanan anket, İngilizce eğitimi alanından iki uzman tarafından Türkçeye çevrilmiş ve karşılaştırma yapılarak çevirinin son hâli ortaya konulmuştur. Daha sonra Türkçe eğitimi alanından iki uzmana Türkçeye çevrilen anket, anlaşılırlık açısından kontrol ettirilmiştir. Son şekli verilen anket uygulanmadan önce pilot çalışma yapılmış ve anketin Cronbah's alfası 0.90 olarak belirlenmiştir. Bu anketten elde edilen veriler SPSS 20 ile analiz edilmiş ve sonuçlar ortalama, standart sapma, sıklık ve yüzde olarak ortaya konularak yorumlanmıştır. Mevcut çalışma özünde Başal ve Elcan-Kaynak’ın 
yaptıkları çalışmanın aynı anket maddeleri ve açık uçlu sorular ve aynı uygulama süreçleri kullanılarak farklı katılımcılarla yapılan bir tekrar (replikasyon) çalışmadır. Tekrar çalışmaları, yapılan bir çalışmanın bulgularının, başka bir yerde başka bir araştırmacı tarafından benzer uygulamalarla elde edilip edilemeyeceğine dair objektiflik ortaya çıkarmaya katkı sağlar (Schmidt, 2009). Tekrar çalışmaları yeni teknolojiler üzerinde yapıldığında söz konusu teknolojilerin potansiyelini ve kullanım alanlarını belirlemeye katkı sağlar (Mackey, 2012).

Çalışmanın nitel boyutunu 4 açık uçlu soru oluşturmaktadır. Bu soruları yöneltmenin amacı, katılımcılardan daha detaylı bilgi almaktır. Görüşme soruları, Başal ve Elcan-Kaynak'ın (2019) çalışmasından alınmıştır. 4 açık uçlu soruya verilen cevaplar, araştırmacılar tarafından içerik analizine tabi tutularak dijital rozetlerin avantaj ve dezavantajlarına yönelik olarak kodlanmış, kategoriler ortaya çıkarılmış ve araştırmacılar tarafından yorumlanmıştır. Çalışmanın nitel yönünü oluşturan açık uçlu sorular şu şekildedir:

1. Dijital rozet aldığınızda kendinizi nasıl hissettiniz?

2. Dijital rozetlerin olası yanıtları nelerdir? Lütfen açıklayınız.

3. Dijital rozetlerin olası dezavantajları nelerdir? Lütfen açıllayınız.

4. Öğretmen olduğunuzda dijital rozet kullanmayı ister misiniz? Lütfen neden kullanmayı istediğinizi ya da istemediğinizi açıklayınız.

\section{Çalışma grubu}

Araştırma 2018-2019 eğitim öğretim yılı bahar yarıyılında gerçekleştirilmiştir. Araştırmanın çalışma grubunu İstanbul'daki bir üniversitenin Türkçe öğretmenliği bölümünde öğrenim gören, Anlama Teknikleri II: Dinleme Eğitimi dersini alan ve araştırmacılarca kullanılan Edmodo öğrenme yönetim sistemine üye olan 48 (Erkek n: 15; Kadın n: 33) öğrenci oluşturmaktadır. Katılımcılar üçüncü sınıf öğrencilerinden oluşmakta olup yaş ortalamaları 21'dir.

\section{Dijital rozetlerin uygulanması}

Araştırmacılar tarafından hazırlanan dijital rozetler, ders sürecince kullanılan ve öğrencilerin kayıtlı olduğu öğretim yönetim sistemi içerisinde var olan rozet oluşturma fonksiyonu ile oluşturulmuştur. Araştırmanın yapıldığı dersin içeriğine göre araştırmacılar tarafından öğrenci performansını nitelendirmeye yönelik olarak 10 rozet oluşturulmuştur (Tablo 1). Rozetler Türkçede yaygın bir deyim olan "kitap kurdu" öbeğindeki "kurt" ibaresi ödünçlenerek oluşturulmuş, "sunum, kelime, özdeyiş, edebiyat, eleştiri, yaratıcılık, espri, katılım ve yazma" alanlarına yönelik olarak kullanılmıştır. Rozetlerin takdim edilme gerekçesi de altlarına yazılmıştır. Bu itibarla öğrencinin rozeti neye istinaden aldığının bilincine varması amaçlanmıştır. Söz konusu rozetler 14 haftalık uygulama süresi boyunca rozet tanımına yönelik olarak gösterdikleri performans durumunda öğrencilerin kendi kişisel sayfalarında (profillerinde) görülmesi amacıyla ilgi dersin hemen akabinde gönderilmiştir. 
Tablo 1. Araştırmacılar Tarafindan Oluşturulan Dijital Rozetler

\begin{tabular}{|c|c|c|}
\hline İkon & Rozet Adı & Tanimı \\
\hline & Sunum Kurdu & Konuya iyi bazulanmıģsın, sunum becerilerin çok iyi \\
\hline & Kelime Kurdu & Senin yas grubunda pek kullanilmayan bir kelimeyi kullandm aferin \\
\hline & Özdeyiş Kurdu & Konu ile ilgili olarak paylaş̆tığı ózdeyiq çok güzeldi. \\
\hline & Edebiyat Kurdu & Konu ile ilgiji olarak paylaştığm şiir / dizeler çok güzeldi. \\
\hline & Eleştiri Kurdu & Sordugğun sorular eleştirel dūşūnme becerinin geliģtiğini gösteriyor \\
\hline & Yaratacilik Kurdu & $\begin{array}{l}\text { Sord́uğun soru ya da verdiğin örnek yaratıcı dügüinme becerinin } \\
\text { geliştiğini gösteriyor }\end{array}$ \\
\hline & Espri Kurdu & Yapttğın eapri çok yerinde idi ve zekâ paraltısı taşyordu. \\
\hline & Katalm Kurdu & Derse oldukça ilguilisin. Bu gözümden kaçmad. \\
\hline & Kitap kurdu & $\begin{array}{l}\text { Her hafta elinde farklı bir kitap görüyorum. Okxma alyłkanligin üst düzeyde } \\
\text { Tebrikler. Devam et. }\end{array}$ \\
\hline & Yazma kurău & $\begin{array}{l}\text { Yazdiklarmi beğeniyorum. Fikir ve sunum yönünden olçukça etkileyici } \\
\text { yazzyorsun }\end{array}$ \\
\hline
\end{tabular}

\section{Verilerin analizi}

14 haftalık "dijital rozet” uygulamasından sonra öğrencilere Başal ve Elcan-Kaynak (2019) tarafından geliştirilen 5'li likert tipindeki ölçek (Hiç katılmıyorum (1) -Çok katılıyorum (5)) ve bu ankete eşlik eden 4 açık uçlu soru katılımcılara Google form ile gönderilmiştir. Toplanan veriler istatistiksel olarak elektronik ortamda analiz edilmiştir. Ayrıca açık uçlu sorulara katılımcılar tarafından verilen cevaplar içerik analizine tabi tutulmuş ve temalar belirlenmiştir. İçerik analizi sözel, yazılı ve diğer materyallerin nesnel ve sistematik bir şekilde incelenmesine olanak tanıyan bilimsel bir yaklaşımdır (Tavşancıl \& Aslan, 2001).

\section{Bulgular ve yorum}

\section{Nicel bulgular}

Çalışmada kullanılan anketten elde edilen sonuçlara bakıldığında (Tablo 2), katılımcıların derslerinde dijital rozet kullanımına yönelik olarak algılarının oldukça olumlu olduğu anlaşllmaktadır. Ankette yer alan 13 maddenin ortalamasının 4,15 gibi oldukça yüksek bir değer çıkması, katılımcıların genel olarak dijital rozetleri oldukça olumlu bulduğunu ispatlar niteliktedir. Anket maddelerinin katılıyorum (4) ve çok katılıyorum (5) birlikte ele alındığında, 6,8 ve 13. maddeler dışında \%70’in üzerinde bir skora sahip olması dijital rozetlerin katılımcılar tarafından olumlu algılandığını da sayısal olarak göstermektedir. Anket maddeleri söz konusu bakımdan ele alındığında en yüksek skora sahip maddeler 87,50 puanla 
aynı skora sahip 1, 3 ve 12. maddelerdir. Bu maddeler sırasıyla katılımcıların dijital rozet aldıklarında kendilerini ödüllendirilmiş hissettiğini, mutlu hissettiğini ve dijital rozetlerin katılımcıların beceri ve başarılarının farkına varması için bir yol sağladığını gösteren maddelerdir. Diğer taraftan düşük bir toplama sahip olmamalarına rağmen (katılıyorum ve çok katılıyorum birlikte ele alındığında) baz alınan \%70'lik skorun altında olan maddeler ise belirtildiği gibi 6 (Rozet alacağım düşüncesi, beni derse daha fazla çalışmaya motive ediyor),8 (Sınıf arkadaşlarımın, rozet aldığını görmek ya da duymak, beni rozet almak için motive ve teşvik ediyor) ve 13. (Sınıftaki arkadaşlarımın, derste aldığım rozetlerden haberdar olmasını isterim) maddelerdir.

Tablo 2. Katılımcı algılarına yönelik anket maddeleri

\begin{tabular}{|c|c|c|c|c|c|c|c|c|}
\hline Anket maddeleri & & 1,00 & 2,00 & 3,00 & 4,00 & 5,00 & $\mathrm{X}$ & SS \\
\hline \multirow{2}{*}{$\begin{array}{l}\text { Derste rozet/rozetler alınca } \\
\text { kendimi ödüllendirilmiş } \\
\text { hissediyorum. }\end{array}$} & Sayı & o & 2 & 4 & 14 & 28 & & \\
\hline & $\%$ & $0,0 \%$ & $4,2 \%$ & $8,3 \%$ & $29,2 \%$ & $58,3 \%$ & 4,4167 & 82083 \\
\hline \multirow{2}{*}{$\begin{array}{l}\text { Rozetlerin diğer derslerimde } \\
\text { kullanılmasını da istiyorum. }\end{array}$} & Sayı & 1 & 5 & 7 & 13 & 22 & & \\
\hline & $\%$ & $2,1 \%$ & $10,4 \%$ & $14,6 \%$ & $27,1 \%$ & $45,8 \%$ & 4,0417 & 1,11008 \\
\hline \multirow{2}{*}{$\begin{array}{l}\text { Öğretmenim bana bir rozet } \\
\text { verdiğinde, kendimi mutlu } \\
\text { hissediyorum. }\end{array}$} & Sayl & 1 & 1 & 4 & 10 & 32 & & \\
\hline & $\%$ & $2,1 \%$ & $2,1 \%$ & $8,3 \%$ & $20,8 \%$ & $66,7 \%$ & 4,4792 & 89893 \\
\hline \multirow{2}{*}{$\begin{array}{l}\text { Rozetlerin, dersteki başarımı- } \\
\text { gelişimimi görmemi sağladığını } \\
\text { düşünüyorum. }\end{array}$} & Sayı & 2 & o & 9 & 14 & 23 & & \\
\hline & $\%$ & $4,2 \%$ & $0,0 \%$ & $18,8 \%$ & $29,2 \%$ & $47,9 \%$ & 4,1667 & $1,0175^{8}$ \\
\hline \multirow{2}{*}{$\begin{array}{l}\text { Rozet alacağım düşüncesi, derse } \\
\text { katılımımı ve ilgimi arttırıyor. }\end{array}$} & Sayı & 3 & 1 & 10 & 13 & 21 & & \\
\hline & $\%$ & $6,3 \%$ & $2,1 \%$ & $20,8 \%$ & $27,1 \%$ & $43,8 \%$ & 4,0000 & 1,14854 \\
\hline \multirow{2}{*}{$\begin{array}{l}\text { Rozet alacağım düşüncesi, beni } \\
\text { derse daha fazla çalışmaya } \\
\text { motive ediyor. }\end{array}$} & Sayı & 4 & o & 15 & 10 & 19 & & \\
\hline & $\%$ & $8,3 \%$ & $0,0 \%$ & $31,3 \%$ & $20,8 \%$ & $39,6 \%$ & 3,8333 & 1,20872 \\
\hline \multirow{2}{*}{$\begin{array}{l}\text { Rozetlerin dersteki başarıma } \\
\text { anında dönüt verdiğini } \\
\text { düşünüyorum. }\end{array}$} & Sayı & 2 & 2 & 9 & 13 & 22 & & \\
\hline & $\%$ & $4,2 \%$ & $4,2 \%$ & $18,8 \%$ & $27,1 \%$ & $45,8 \%$ & 4,0625 & 1,09944 \\
\hline \multirow{2}{*}{$\begin{array}{l}\text { Sınıf arkadaşlarımın, rozet } \\
\text { aldığını görmek ya da duymak, } \\
\text { beni rozet almak için motive ve } \\
\text { teşvik ediyor. }\end{array}$} & Sayı & 2 & 3 & 11 & 12 & 20 & & \\
\hline & $\%$ & $4,2 \%$ & $6,3 \%$ & $22,9 \%$ & $25,0 \%$ & $41,7 \%$ & 3,9375 & 1,13749 \\
\hline \multirow{2}{*}{$\begin{array}{l}\text { Derslerde rozet kullanılmasının, } \\
\text { yaratıcı bir değerlendirme } \\
\text { yaklaşımı olduğunu } \\
\text { düşünüyorum. }\end{array}$} & Sayı & 1 & o & 7 & 14 & 26 & & \\
\hline & $\%$ & $2,1 \%$ & $0,0 \%$ & $14,6 \%$ & $29,2 \%$ & $54,2 \%$ & 4,3333 & 88326 \\
\hline \multirow{2}{*}{$\begin{array}{l}\text { Derste rozet kullanılmasını } \\
\text { sevdim çünkü derse eğlence } \\
\text { katıyor. }\end{array}$} & Sayı & o & 2 & 6 & 10 & 30 & & \\
\hline & $\%$ & $0,0 \%$ & $4,2 \%$ & $12,5 \%$ & $20,8 \%$ & $62,5 \%$ & 4,4167 & 87113 \\
\hline
\end{tabular}




\begin{tabular}{|c|c|c|c|c|c|c|c|c|}
\hline \multirow{2}{*}{$\begin{array}{l}\text { Ödev ya da projeleri } \\
\text { tamamladıktan sonra rozet } \\
\text { kazanmak, dersten aldığım zevki } \\
\text { arttırıyor. }\end{array}$} & Sayı & 1 & 2 & 7 & 11 & 27 & \multirow[b]{2}{*}{4,2708} & \multirow[b]{2}{*}{1,00508} \\
\hline & $\%$ & $2,1 \%$ & $4,2 \%$ & $14,6 \%$ & $22,9 \%$ & $56,3 \%$ & & \\
\hline \multirow{2}{*}{$\begin{array}{l}\text { Derste rozet kullanılması, } \\
\text { ŏğrencilere, beceri ve } \\
\text { başarılarının farkına varması için } \\
\text { bir yol sağlıyor. }\end{array}$} & Sayı & 1 & 1 & 4 & 14 & 28 & & \\
\hline & $\%$ & $2,1 \%$ & $2,1 \%$ & $8,3 \%$ & $29,2 \%$ & $58,3 \%$ & 4,3958 & 89299 \\
\hline \multirow{2}{*}{$\begin{array}{l}\text { Sinıftaki arkadaşlarımın, derste } \\
\text { aldığım rozetlerden haberdar } \\
\text { olmasını isterim. }\end{array}$} & Sayı & 5 & 5 & 11 & 8 & 19 & & \\
\hline & $\%$ & $10,4 \%$ & $10,4 \%$ & $22,9 \%$ & $16,7 \%$ & $39,6 \%$ & 3,6458 & 1,37593 \\
\hline
\end{tabular}

\section{Nitel bulgular}

Çalışmanın nitel bölümünde katılımcıların açı uçlu sorulara verdiği cevaplar analiz edilmiştir. Katılımcılar "Rozet aldığınızda kendinizi nasıl hissediyorsunuz? sorusuna dikkate değer kısmı $(n=22)$ mutlu olduğunu belirtirken, bunu diğer olumlu duygu ifadeleri takip etmektedir. Şekil 1'de görüldüğü üzere, katılımcılar dijital rozet aldıklarında olumlu duygulara sahiptir.

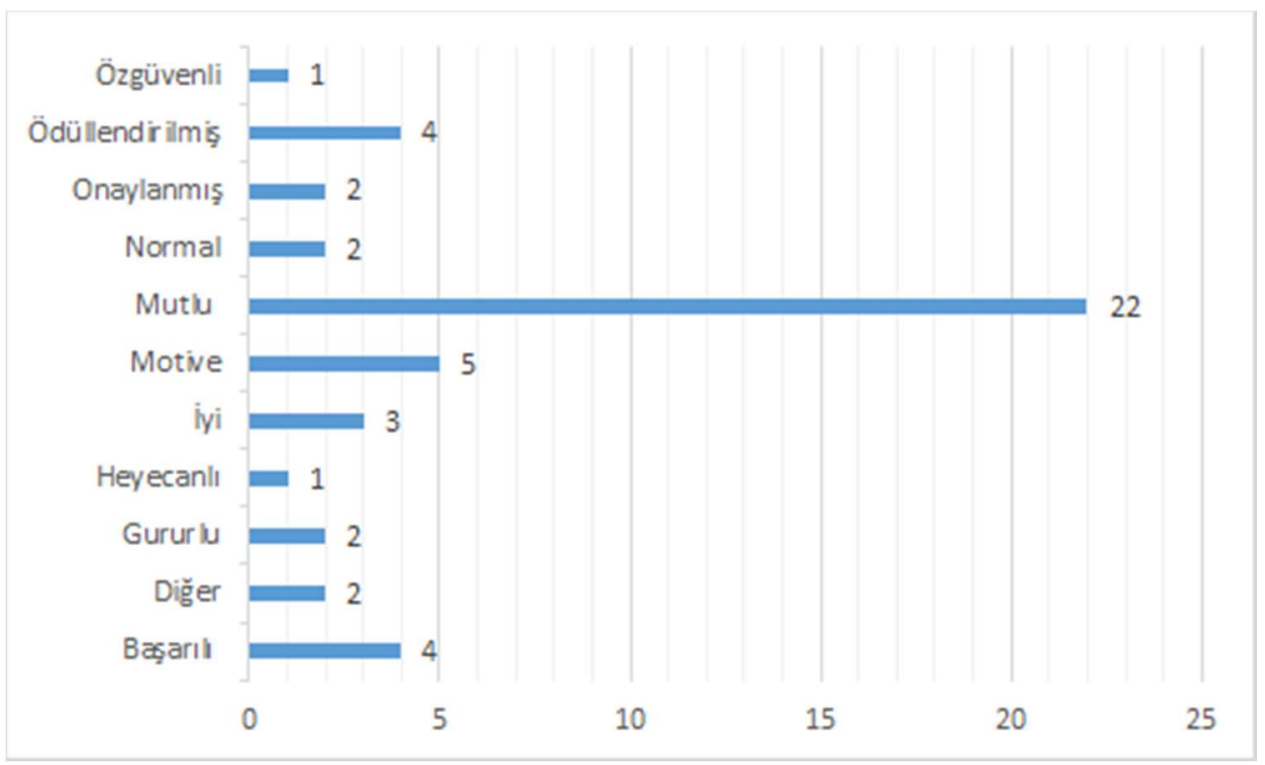

Şekil 1. Rozet aldı̆̆ınızda kendinizi nasıl hissediyorsunuz?

Katılımcıların verdiği cevaplardan bazıları aşağıdaki gibidir :

Okutman tarafından aldığım değer ve emeğin boşa gitmediğini görmek beni mutlu ediyor.

Doğru yolda olduğumu ve böyle devam etmem gerektiğini düşünüp mutlu oluyorum.

O gün derste üzerime düşeni yapmış olduğumu düşünerek mutlu hissediyorum.

İlk defa böyle bir uygulamayla karşılaşıyorum. Rozet alınca kendimi derse karşı daha motive olmuş hissediyorum.

Kendimi derste gösterdiğim performanstan dolayı ödüllendirilmiş hissediyorum.

Yukarıda sıralan öğrenci ifadelerinden, öğrencilerin dersteki performanslarına yönelik aldıkları dijital rozetlerin onlarda olumlu duyguların oluşmasına katkı sağladığı görülmektedir. Diğer olarak belirtilen 
kısımda ise 2 öğrencinin aşağıda verilen ifadelerden rozet alma konusunda olumsuz hisler beslediği veya rozet almadığı için herhangi bir yorum yapamadığı görülmektedir.

Hiç rozet almadığım için bunun nasıl bir duygu yaşatacağını bilmiyorum.

Daha fazla rozet çeşitliliği sağlanabilirdi. Bu hâliyle sessiz bir öğrenci oluşumdan dolayı bazı rozetler bana uymuyor. Benim gibi öğrenciler içinde bir şeyler yapılabilirdi.

\section{Dijital rozetlerin avantajları}

Dijital rozetlerin kullanımının olası avantaj ve dezavantajlarına yönelik olarak 2 açık uçlu soru ile katılımcılara görüşleri sorulmuştur. Tablo 3 ’te katılımcıların cevaplarına yönelik olarak içerik analizi ile ortaya çlkarılan temalar toplu olarak görülmektedir.

\section{Tablo 3. Dijital rozetlerin avantaj ve dezavantajları}

\begin{tabular}{|c|c|}
\hline Avantajları & Dezavantajları \\
\hline Öğrencileri motive etme & Rozet alamamanın rahatsızlığı \\
\hline Derse ilgiyi artırma & Yarışmacı ortam yaratma \\
\hline Dönüt sağlama & Kalabalık sinıflarda rozet elde etmenin zor olması \\
\hline \multicolumn{2}{|l|}{ Ders içi rekabeti artırma } \\
\hline \multicolumn{2}{|l|}{ Dersi eğlenceli hâle getirme } \\
\hline \multicolumn{2}{|l|}{ Öğrenci özgüvenini artırma } \\
\hline \multicolumn{2}{|l|}{ Derse katılımı artırma } \\
\hline \multicolumn{2}{|l|}{ Öğrenci-öğretmen iletişimini geliştirme } \\
\hline \multicolumn{2}{|l|}{ Derse devamı sağlama } \\
\hline $\begin{array}{l}\text { Öğrencilerin beceri ve yeteneklerinin farkına } \\
\text { varmasını sağlama }\end{array}$ & \\
\hline
\end{tabular}

Dijital rozetlerin avantajlarına yönelik verilen cevapların analizinden on tema tespit edilmiştir:

Öğgrencileri motive etme: Katılımcılar çalışma kapsamında dersleri boyunca kendilerine gönderilen dijital rozetlerin kendilerini derse karşı motive ettiklerini dile getirmiştir. Bu noktada katılımcılardan bazılarının ifadeleri aşağıdaki gibidir:

Rozet alan öğrencilerin motivasyonu artar.

Derse motive olma noktasında katkı sağlar.

Derse ilgiyi arttrma: Katılımcılar dijital rozetlerin derse olan ilgilerini artırdığı yönünde görüşler ortaya koymuştur:

Dağıtılan rozetler öğrencilerin derse olan ilgisini artırabilir.

Rozeti Edmodo’da gördüğümde derse karşı olan ilgim gerçekten arttı. 
Dönüt sağlama: Dijital rozetler öğrencilerin dersteki performansları ile ilgili olarak anında dönüt sağlayan araçlardır. Bu noktada katılımcı ifadeleri de bu aracın dönüt sağlamada etkili olduğunu ortaya koymaktadır:

Öğrenci bir konuda başarısını anında görme imkânına sahip olur.

Derslerde en büyük sorun dönüt almama veya geç dönüt alma oluyordu. Fakat bu derste aldığım dijital rozetler dersin hemen sonrasında derse katılımım ve katkımla ilgili hızlı dönüt sağlayıp ne durumda olduğumu göstermesi bakımından oldukça önemli idi.

Ders içi rekabeti arturma: Dijital rozetler dersteki rekabeti artırma noktasında katılımcılar tarafından hem bir avantaj ve hem de bir dezavantaj olarak görülmüştür. Avantaj olarak gören katılımcıların ifadelerinden bazıları aşă̆ıdaki gibidir:

Olumlu bir rekabet ortamı yaratabilir.

Derste öğrencilerin birbirleri ile çekişmesini sağlayarak yarışmacı ve tatlı bir rekabet ortaya çıkarır.

Dersi ĕglenceli hâle getirme: Oyunlaştırma temeli üzerine kurulu olan dijital rozetlerin bu yönü katılımcı ifadelerinde dersi daha eğlenceli hâle getirme noktasında ortaya çıkmaktadır. Söz konusu duruma dair öğrenci görüşleri aşă̆ıdaki gibidir:

Alışılmadık ve sürpriz şeklinde olduğu için ders sanki daha eğlenceli hâle geliyor.

Rozet resmi, tanımı ve açıllaması beni eğlendiriyor.

Öğgrenci özgüvenini arthrma: Dijital rozetlerin öğrenci performansına yönelik taşıdı̆̆ı olumlu ifadeler, katılımcı görüşlerinde de görüldüğü gibi öğrencilerin özgüvenini artırmaya katkı sağlamaktadır:

Rozet aldığımda kendime güvenim geliyor.

Takdir edilmek özgüvenimi artırıor.

Derse katılım arturma: Derslerde öğrencilere gösterdikleri performans karşılı̆̆ında rozet vermek öğrencilerin derse daha fazla katılmaya istekli olmalarının önünü açmaktadır. Bu noktadaki katılımcı görüşlerinden bazıları aşağıdaki gibidir.

Rozet almaya alıştıkça derste daha aktif olmaya çalışıyorum.

Rozet almak keyif verdiği için derse daha fazla katılmaya istekli oluyorum.

Öğgrenci-öğretmen iletişimini geliştirme: Öğrenci ve öğretmen arasındaki iletişimin performansa ve derse başarıya etkisinin yüksek olduğu düşünüldüğünde, katılımcıların çalışma kapsamında kullanılan dijital rozetlere yönelik ifadeleri oldukça önem arz etmektedir:

Öğrenci-öğretmen arasında keyifli bir bağ kurulmasını sağlıyor.

Rozetler sanki öğrenci ve öğretmen arasında sözlü iletişim hâlinde olmayan yeni bir iletişim kanalı sağllyor.

Derse devamı sağlama: Derse devamlılık öğrenci başarısını artırmada ve dersin etkili bir şekilde takibinde üzerinde durulması gereken konudur. Dijital rozetlerinde bu noktada katkı sağlaması dikkat çekicidir.

Derse gelmeye daha fazla istek duyuyorum. 
Bu dönem özellikle bu derse fazla devamsızlık yapmamak istedim çünkü gelemediğim zamanlarda rozet almamak düşüncesi hâkim oldu bende.

Öğrencilerin beceri ve yeteneklerinin farkma varmasını sağlama: Dijital rozetlerde yer alan performansa yönelik tanımlayıcı ve olumlayıcı ifadeler öğrencilerin kendi beceri ve yeteneklerini fark etmesini sağlamaya katkı vermektedir.

Kişiler kendilerinde farkında olmadıkları ilgi ve yeteneklerini bu rozetler ile fark edebilirler.

Öğrencinin farkında olmadığı fakat kendisinde var olan birtakım yetenekleri keşfetmesini sağlayabilir.

\section{Dijital rozetlerin dezavantajları}

Dijital rozetlerin dezavantajlarına yönelik verilen cevapların analizinde üç tema tespit edilmiştir:

Rozet alamama: Çalışma kapsamında dijital rozetler; katılımcıların olası sınıf içi performanslarına göre tasarlanmış ve belirlenen performans kriterlerini gösteren katılımcılara dağıtılmıştır. Bu kriterler paralelinde performans göstermeyen veya gösteremeyen öğrenciler dijital rozet alamamıştır. Bu durum katılımcı görüşlerinde kendini göstermektedir:

Alamayan öğrencinin motivasyonu düşer.

Başarılı ama derslerde aktif olmayan bir öğrenci olduğum için hiç rozet alamadım.

Rozet al(a)mayan öğrencilerin kendini eksik hissetmesi olasıdır.

Rozetlerin çok farklılaştırılması ve sayıca çok fazla olması lazım çünkü alamayan öğrenciler olabiliyor.

Yarışmacı ortam yaratma: Bu tema benzer şekilde "ders içi rekabeti artırma" teması olarak avantajlar kısmında ele alınmıştır. Öte yandan bu rekabet kimi katılımcılar tarafından dijital rozetlerin dezavantajı olarak değerlendirilmiştir:

Öğrenciler arasında yarışmacı bir ortama sebebiyet verebilir.

Rekabet duygusu yılgınlık yaratabilir, içe kapanma olabilir.

Öğrenciler arasında manasız rekabetler çıkabilir.

Kalabahk sınıflarda rozet elde etmenin zor olması: Çalışma kapsamında olası performans kriterlerine göre tanımlanan ve dağıtılan dijital rozetler öğrencinin derse çeşitli şekillerde katılımını gerektirmektedir. Katılımcı görüşlerinden anlaşılacağı üzere, sınıf mevcudunun kalabalık olması dijital rozet alımını zorlaştırmaktadır.

Sınıflar kalabalık olduğu için kişiler aktif olamıyor.

Kalabalık sınıflarda derse katılım, kendini göstermede vakit ve fırsat sıkıntısı yaşanabiliyor. Bu yüzden bazı öğrenciler gözden kaçabiliyor.

Dördüncü açık uçlu soru, çalışmaya katılan Türkçe öğretmeni adaylarının gelecekte rozet kullanıp kullanmayacaklarını belirlemeye ve her iki açıdan da bunun olası nedenlerinitespit etmeye yöneliktir. $\mathrm{Bu}$ soruya katılımcıların büyük çoğunluğu $(n=45$, \%93.75) öğretmen olduklarında dijtal rozet kullanacaklarını belirterek cevap vermiştir. Katılımcıların bu yönde ileri sürdükleri nedenlerinden bazıları aşă̆ıdaki gibidir:

Evet isterim. Çünkü pekiştireç olmuş olur. 
İsterim. Çünkü özellikle alt yaş düzeyindeki smıflarda bu tip ödüller motivasyonu artırıcı ve teşvik edici olabilir.

Evet kesinlikle istiyorum. Ortaokul öğretmeni olacağım için o yaştaki öğrencilerin böyle şeylere ihtiyacı vardır. Hem de eğlenceli geçen ders sayısı artar.

Evet isterim. Öğrencilerimle aramdaki ilişkiyi güçlendireceğini ve derste daha aktif olacaklarını düşünüyorum.

Evet isterim. Zira biz üniversite öğrencisi olduğumuz hâlde bu denli zevk veriyor ise daha küçük yaş gruplarında başarı duygusunun tattırıması ve derse güdüleme açısından başarılı olacağını düşünüyorum.

Rozet uygulamasını kullanmak istiyorum. Öğrencilerin derse olan ilgilerinin artmasını ve bu sayede eğitim öğretim programında yer alan bilgileri, kendi arzularıyla, edinmesini isterim.

İsterim çünkü öğrencileri farklı alanlarda güdüleyebilir. Örneğin; kitap kurdu rozeti çocuklara okuma alışkanlığı kazandırmada rol oynayabilir. Yazma kurdu rozeti öğrencinin yazma yeteneğini keşfedip bunun üzerinde kendini geliştirmesini sağlayabilir.

İstiyorum.

Değerlendirmelerin ve derslerin gelenekselleşmişsliğinden ve sıkıcllı̆̆ından uzaklaşarak eğlenerek öğrenme ortamı oluşturmaya yarar göstereceği inancındayım.

Diğer taraftan katılımcıların çok küçük bölümü ( $\mathrm{n=2,} \% 4.16)$ dijital rozetleri kullanmayacaklarını ve sadece 1 katılımcı da $(\% 2,8)$ emin olmadığını belirterek cevap vermiştir:

\begin{abstract}
İstemem çünkü çalışkan olup da utangaç olan insanlar vardır ve utangaçlıklarından ötürü bildiği şeyleri de söylemeyebilir diye düşünüyorum.

İstemezdim, öğrencilerimi bu şekilde kriterlerine göre ayırmak yerine kendi kişisel özelliklerine göre yardımcı olmak isterim
\end{abstract}

Kullanmak istemem çünkü utangaç, çekingen ama çalışkan öğrenciler bu durumdan rozet alamayarak olumsuz etkilenebilirler.

Eğer kalabalık sınıfsa istemem.

Kullanmak istediğimden emin değilim.

\title{
Tartışma ve sonuç
}

Dijital rozet öğrenci başarısını belirlemeye, tanımlamaya ve desteklemeye yönelik belirlenen kriterler doğrultusunda öğrenciye verilen görsel, başlık ve tanımlayıcıdan oluşan araçlar olarak tanımlanabilir. Mevcut çalışma kapsamında olası ders içi performans kriterleri belirlenmiş ve dijital rozetler; katılımcı Türkçe öğretmeni adaylarının Edmodo üzerindeki profillerine rozetlerde tanımlanan performans kriterlerden herhangi birini sergilediğinde gönderilmiştir. Çalışma sonuçları, dijital rozetlerin öğrenciler tarafından büyük ölçüde olumlu olarak algılandığını göstermektedir. Hem nicel hem de nitel verilerin analizi katılımcıların bu algısını teyit etmektedir. Bu sonuç Başal ve Elcan-Kaynak’ın(2019) çalışmaları ile benzerlik göstermektedir. Yine söz konusu çalışma ile karşılaştırıldığında her iki çalışmada da katılımcıların rozet aldığınızda kendinizi nasıl hissedersiniz sorusuna verdiği yanıtlarda mutluluk ve motive edicilik ilk sıralarda yer almaktadır. Buna ek olarak, iki çalışmada rozetlerin avantaj ve dezavantajlarına yönelik çıkarılan temalarda benzerlik göstermektedir. Avantaj açısından mevcut çalışmada 10 temaya ulaşılırken, diğer çalışmada 7 temaya ulaşılmıştır. Mevcut çalışma farklı olarak derse devamı sağlama, öğrenci-öğretmen iletişimini geliştirme ve öğrencilerin kendi beceri ve yeteneklerinin farkına varmasını sağlama temalarını ortaya çıkarmıştır. Dezavantajlar bakımından ele alındığında kalabalık sınıflarda rozet elde etmenin zorluğu teması mevcut çalışmada ek tema olarak ortaya çıkmıştır. Genel olarak değerlendirildiğinde dijital rozetlere yönelik olarak her iki çalışmada da katılımcıların oldukça yüksek düzeyde olumlu algılar taşıdığı görülmektedir. Mevcut çalışma, Başal ve 
Elcan-Kaynak'ın (2019) çalışmasında ortaya konan dijital rozetlere karşı olumlu katılımcı algılarını farklı katılımcı grubu açısından göstermekte ve dijital rozetlerin derslerde kullanılmasının olumlu yönlerini güçlendirmektedir.

Mevcut çalışmada dijital rozetlere ilişkin katılımcı görüşlerinden yola çıkılarak elde edilen avantajları arasında sıralanan temalardan ders içi rekabeti artırma, derse ilgiyi artırma, özgüveni artırma ve öğrencileri motive etme; dijital rozetlerle ilgili öğrenci görüsslerini belirleyen bazı çalışmalarla benzerlik göstermektedir (Ylldırım vd., 2014).illköğretim öğrencilerinin Edmodo ile ilgili görüşlerini irdeleyen bir çalışmada (Dere, Yücel, Yalçıntaş, 2016), bu platform aracılı̆̆ıyla rozet alan öğrencilerinin derse karşı ilgilerinin ve motivasyonlarının arttığı bulgusu mevcut çalışmanın sonuçları ile örtüşmektedir. Mevcut çalışmanınkinden farklı olarak, dijital rozetlere karşı öğretmen görüşlerinin belirlendiği bir diğer çalışmada (Hebebci \& Usta, 2018), farklı branşlarda olan katılımcı öğretmenlerin dijital rozetlere karşı olumlu görüşlere sahip olmaları ve öğrenci davranışlarını olumlu etkileme, derse karşı motivasyonu artırma ve öğrencilerin derse aktif katılımını ve ilgisini sağlama noktasında görüşleri bu çalışmadaki katılımcı görüşleriyle benzerlik göstermesi; öğrenci ve öğretmenlerin dijital rozetlerle ilgili olarak benzer görüşlere sahip olmaları bakımından önemlidir. Diğer taraftan, aynı çalışmada öğretmenlerin öğrenciler arası rekabeti olumsuz görmesi de mevcut çalışmada dijital rozetlerin yarışmacı ortam yaratma temasında belirtilen dezavantajı ile örtüşmektedir. Mevcut çalışma ile ortaya konan dijital rozetlerin kullanımının öğrenciyi motive etmede etkin bir araç olduğu bulgusunu da destekleyen çalışmalar mevcuttur (Alaswad\&Nadonly, 2015 ;Gibson vd., 2015; Hakulinen, 2015 ;Ylldırım vd., 2017). Mevcut çalışmanın dijital rozetlerin derse öğrenci katılımını artırdığı bulgusu ile örtüşen çalışmalar da bulunmaktadır (Deny, 2013).

Çalışma kapsamında kullanılan dijital rozetlere yönelik katılımcı algılarının genel olarak olumlu olduğu ve rozet kullanımının avantajlarının dezavantajlarından çok daha fazla olduğunu gösteren bu çalışma, söz konusu rozetlerin sınıftaki öğrenci performansına katkıları bakımından alternatif bir ödül ve değerlendirme sistemi olarak kullanılmasının faydalı olacağını göstermektedir. Dijital rozet hazırlarken, rozetlere yerleştirilecek performans göstergelerinin dersin amaçları doğrultusunda ve geniş bir yelpazede hazırlanması gerekliliği çalışma kapsamında katılımcıların belirttiği rozetlerin kimi dezavantajlarının giderilmesine katkıda bulunacağı, bir ödül ve değerlendirme aracı olarak etkililiğini artıracağı ortadadır.

Mevcut çalışma yalnızca Türkçe öğretmeni adaylarının dijital rozetlere karşı algılarını belirlemesi yönüyle, farklı popülasyonlara yönelik saptamaların yapılmasını zorlaştırması yönüyle sınırlıdır. Dijital rozetlere karşı farklı katılımcı gruplarının görüşlerini belirlemeye yönelik olarak ek çalışmalar yapılabilir. Bu çalışmada cinsiyet yönünden farklı algılamaların olup olmadığına odaklanılmamış; dolayısı ile cinsiyete göre algılar arasında benzerlik ya da farklılıklar olup olmadığını bir alt problem olarak benimseyen çalışmaların yapılması da ehemmiyet arz etmektedir.

\section{Kaynakça}

Ahn, J., Pellicone, A., \& Butler, B. S. (2014). Open badges for education: What are the implications at the intersection of open systems and badging?.Research in Learning Technology, 22: 23563 http://dx.doi.org/10.3402/rlt.v22.23563

Akbaba, S. (2006). Eğitimde motivasyon. Kazım Karabekir Eğitim Fakültesi Dergisi, 13, 343-361.

Alaswad, Z., \& Nadolny, L. (2015). Designingfor Game-Based Learning: The Effective Integration of Technology to Support Learning. Journal of Educational Technology Systems, 43(4), 389-402. 
Başal, A., \& Elcan-Kaynak, N. (2019). Perceptions of Pre-service English Teachers towards the use of digital badges. Yayıma gönderilen makale.

Bozkurt, A., \& Genç-Kumtepe, E. (2014). Oyunlaştırma, Oyun Felsefesi ve Eğitim: Gamification. Akademik Bilişim'14 - XVI. Akademik Bilişim Konferansı Bildirileri. S.147-156.

Casilli, C., \& Knight, E. (2012, June 11). 7 Things You Should Know About Badges. EDUCASE: http://www.educause.edu/ir/library/pdf/ELI7085.pdf adresinden alındı

Cheng, C. H. (2001). The preferred learning and teaching styles at a selected juniour college in Taiwan (China). EdDDissertation. China: University of South Dakota.

Creswell, J. (2009). Researchdesign: Qualitative, quantitative, and mixed methods approaches (3rd ed.). London, UK: Sage.

Davis, K.,\& Singh, S. (2015). Digital badges in after school learning: Documenting the perspectives and experiences of students and educators. Computers\&Education, 88, 72-83.

Denny, P. (2013). The effect of virtual achievements on student engagement. In Proceedings of the SIGCHI conference on human factors in computing systems (pp. 763-772). NewYork, NY, USA: ACM.

Dere, E., Yücel, Ü. A., \& Yalçınalp, S. (2016). İlköğretim Öğrencilerinin Eğitsel Bir Çevrimiçi Sosyal Öğrenme Ortamı Olan Edmodo'ya İlişkin Görüşleri. İlköğretim Online, 15(3), 804-819

Eales, R. T. J., Hall, T., \& Bannon, L. J. (2002). The motivation is the message: comparing cscl in different settings. İçinde: Proc. of CSCL 2002, International Society of the Learning Sciences, ss. $310-317$.

Gates, B. (2000, Aralı 1). Shaping the Internet Age. Microsoft News Center: http://news.microsoft.com/2000/12/01/shaping-the-internet-age/ adresinden alındı.

Gibson, D., Ostashewski, N., Flintoff, K., Grant, S., \& Knight, E. (2015). Digital badges in education. Education and Information Technologies, 2O(2), 403-410.

Güler, C., \& Güler, E. (2015). Çevrimiçi öğrenme ortamlarında oyunlaştırma: Rozet kullanımı. Eğitim ve Öğretim Araştırmaları Dergisi Journal of Research in EducationandTeaching, 4(3), Cilt:4 Sayı:3

Hakulinen, L., Auvinen, T., \& Korhonen, A. (2015). The effect of achievement badges on students' behavior: An empirical study in a university-level computer science course. International Journal of Emerging Technologies in Learning (IJET), 1O(1), 18-29.

Hebebci, M. T., \& Usta, E. (2018). Eğitim ortamlarında dijital rozet kullanımına ilişkin öğretmen görüşleri. Türk Bilgisayar ve Matematik Eğitimi Dergisi, 9(2), 192-210.

Kandemir, C. M. (2014). Dijital Rozetler ve Eğitim Amaçh Kullanımı. 8. Uluslararası Bilgisayar ve Öğretim Teknolojileri Sempozyumu Bildiriler Kitabı, s.373-377.

Karatay, H., Karabuğa, H. \& İpek, O. (2018). Türkçenin yabancı dil olarak öğretiminde Edmodo’nun kullanımı: Bir durum çalışması. Ana Dili Eğitimi Dergisi, 6(4), 1064-1090.

Mackey, A. (2012). Why (or why not), when and how to replicate research. İçinde G. Porte (Eds.), Replication research in applied linguistics, (ss 21-47). Cambridge: Cambridge University Press.

Sailer, M., Hense, J., Mandl, H., \& Klevers, M. (2013). Psychological Perspectives on Motivation through Gamification. Interaction Design and Architecture(s) Journal, 19, 28-37.

Şahin, M. \& Samur, Y. (2017). Dijital Çağda Bir Öğretim Yöntemi: Oyunlaştırma. Ege Eğitim Teknolojileri Dergisi, 1(1), 1- 27.

Schmidt, S. (2009). Shall we really do it again? The powerful concept of replication is neglected in the social sciences. Review of General Psychology, 13(2), 90-100.

Tavşancıl, E., \& Aslan, E. (2001). İ̧erik analizi ve uygulama örnekleri.İstanbul: Epsilon Yayıncılık. 
Tunga, Y., \& İnceoğlu, M. M. (2016). Oyunlaştırma Tasarımı. 3. Uluslararası Eğitimde Yeni Yönelimler Konferans1,267-279.

Werbach, K., \& Hunter, D. (2012). Forthewin: How game thinking can revolutionize your business: Wharton Digital Press.

Yıldırım, S. Çelik, E., Kaban, A., \& Yıldırım, G. (2017). Değerlendirme sürecinde dijital rozetlerin kullanımı ve öğrenen görüşleri. Mehmet Akif Ersoy Üniversitesi Sosyal Bilimler Enstitüsü Dergisi, 9(22), 173-193.

Yıldırım, S., Yıldırım, G., Çelik, E. \& Kara, A. (2014). Dijital rozetlere yönelik öğrenci görüşlerinin belirlenmesi. Eğitim ve Öğretim Araşttrmaları Dergisi 3(4), 208-216. 